\title{
Realization of Copyright in Russia in the Sphere of Scientific Articles: The Experience of Applied Sociological Analysis
}

\author{
Elena Eugenievna Tarando ${ }^{1}$, Yury Vladimirovich Mishalchenko ${ }^{2}$, Nikolay Alexandrovich Pruel ${ }^{3}$, Olga \\ Alexandrovna Nikiforova ${ }^{4} \&$ Tatiana Borisovna Malinina ${ }^{5}$ \\ 1 Faculty of Sociology, Department of Economic Sociology, Saint-Petersburg State University, Russian \\ Federation \\ ${ }^{2}$ Faculty of International Relations, Department of European Studies, Saint-Petersburg State University, Russian \\ Federation \\ ${ }^{3}$ Faculty of Sociology, Department of social management and planning, Saint-Petersburg State University, \\ Russian Federation \\ 4 Faculty of Sociology, Department of Economic Sociology, Saint-Petersburg State University, Russian \\ Federation \\ ${ }^{5}$ Faculty of Sociology, Department of Social Analyses and mathematical methods in Sociology, Saint-Petersburg \\ State University, Russian Federation \\ Correspondence: Elena Eugenievna Tarando, Building 36, Block 8, fl. 210, Dachny prospekt, 198215, Saint \\ Petersburg, Russian Federation
}

Received: December 23, $2014 \quad$ Accepted: December 30, $2014 \quad$ Online Published: February 25,2015
$\begin{aligned} & \text { doi:10.5539/res.v7n3p113 } \\ & \text { URL: http://dx.doi.org/10.5539/res.v7n3p113 }\end{aligned}$

\begin{abstract}
In this paper we on the basis of expert interview method generalize and analyze real social practices of Russian scientific journals linked to the realization of copyright allocation when publishing scientific articles. It was found that conclusion of written copyright agreement is performed only in exceptional cases and there are three types of such cases. The analysis of copyright allocation between an author and a journal showed the dependence of the allocation on the journal's policy. As a rule, practically all the property rights, except for the right for author's copy, are passed to journal. We also analyze the conditions for allocation of journal's issues in the Internet. We have established that policy of Russian journals often includes granting of open access to articles. Main types of violations committed by Russian authors in respect of journals are generalized. The authors of the paper come to the conclusion that despite the fact the legislative framework concerning turnover and protection of intellectual property in the Russian Federation is by and large formed, the everyday practice in this area demonstrates significant stagnation in implementation of legally set standards. The realization of copyright in the sphere of publication of scientific articles in Russian journals in everyday practice is mainly regulated by the system of informal standards. Among them there are still the standards applied in the Soviet times.
\end{abstract}

Keywords: copyright, copyright agreement, royalty, strategies of behaviour of journals, allocation of copyright

\section{Introduction}

The integration of Russian science into the world scientific community causes the number of problems linked to the necessity of formation in Russia of scientific space that would comply with world's standards in this area. One of such problems is the problem of institutionalization of civilized standards for copyright in Russian practice of publication of scientific articles in correspondent journals. The research conducted by us shows that such institutionalization has just started and is being quite far from its completion, while the dialogue between Russian and world science requires equivalence of Russian standards that realize the copyright in the sphere of publication of scientific articles to the standards of modern civilization.

The aims of this paper are: analysis of main problem areas of copyright realization in the sphere of publication of scientific articles in Russian scientific journals and generalization and analysis of strategies of behaviour of scientific journals in the domain of copyright.

The present analysis gives us opportunity of finding the ways for further improvement of Russian journals' work 
with authors, implementation to the practice of this work of social norms promoting the integration of Russian science into the world scientific process.

\section{Literature Review}

The development of copyright problematics in both-western and Russian scientific literature-is being the prerogative of the legal fraternity. However, in the western literature along with common works, which reveal main principles for construction of system and functioning of copyright (Bently \& Sherman, 2001; Blanco White \& Jacob, 1986; Ramalho A, 2014; Peukert, 2011; Kunstadt, 2014), there are works illustrating separate aspects for realization of copyright for products of science (Pila, 2010). Thus, there are wide-spread discussions of matters linked to the specificity of requirements to the degree of work's originality that allows considering it as of authorship (Lavik \& van Gompel, 2013; Gervais, 2002; Rahmatian, 2013). In these works various approaches are covered and the solutions on defining the degree of originality in legislations of developed countries are suggested.

The emphasis is put on the researches related to the studying of permissible degree of freedom of expression in works of authorship (Geider \& Izyumenko, 2014). It is noted that such freedom has definite limits that should be explicitly defined.

Another one topic of the day in the sphere of copyright realization covers its protection (Roland, 2014; Kazi, 2011; Kozinski, 2013; Pallante, 2013). It is said that the strategies of violations linked to copyright become more sophisticated and refined. In such a situation the legislation should respond to such changes correspondingly.

Researchers dealing with the matters of copyright evolution point out rather contradictive tendencies in its development. Thus, there are the processes leading to definite unification of legislative regulations for copyright realization in different states (The Witterm Groupe, 2011; Harding \& Sweetland, 2012), but at the same time there is the necessity of preservation of cultural specificity typical for each separately taken country (Burfitt \& Heathcote, 2014; Arnesen, 2014). This line of researches has great significance for Russia, the science of which on the one hand should integrate into the world scientific community and on the other hand should preserve definite original characteristics of scientific process proven their efficiency in specific social and legal and social-economic conditions peculiar for Russia.

In the Russian scientific legal literature there are also works illustrating the general principles of copyright (Semiletov, 2000; Sudarikov, 2009). We should note that since the copyright as legal conception was introduced to Russian legal framework not so much time ago, the actual matters of scientific discussions cover such aspects as legal certainty of intellectual property objects in general and copyright in particular, their classification (Zimin, 2014a; Makhonina, 2014), interrelation between "intellectual property" and "intellectual rights" concepts (Zimin, 2014b), specificity of information and knowledge as the object of property (Semiletov, 2000).

The aspects of absolute importance are the aspects of protection of intellectual rights in general and copyright in particular (Skopintsev, 2008), i.e. in the sphere of publication of scientific articles in Russian scientific journals (Linet, 2000; Dobryakova, 2012). The certainty of copyright in this sphere is also being of interest for researchers (Zenin, 2012a; Zenin, 2012b; Dobryakova, 2012). At the same time it is noted that formation of social and legal field equivalent to world's standards is the condition for sound integration of Russia into Bologna process and the condition for possibility of gaining academic degree by foreign citizens in Russia (Malyshev \& Pruel, 2014).

What is for sociologists, according to the comment of Swedberg, R., they do not try to research the sphere of property (Swedberg, 2003). This holds true for intellectual property as well. Up to date the only western paper in the area of sociological research of property and intellectual property is perhaps the work of Carruthers, B. and Ariovich, L. (Carruthers \& Ariovich, 2004). What is for Russia the emerging of "intellectual property" and "copyright" concepts in its legal framework causes the problem of modernization of scientific process performance practice, i.e. in the sphere of publication of articles in scientific journals. In the context of sociology this problem means the necessity of monitoring of social practices for performance of activity in this sphere with a view to their compliance with adopting legislative standards; the necessity for analysis of how much the practice succeeds to change following the changes of legislation. In the present time in Russia there are no researches concerning such matters within the problematics of copyright. The present paper was designed to close this gap. 


\section{Materials and Methods}

\subsection{The Legal Conditions for Performance of Articles' Publication in Scientific Journals in the Russian Federation}

Following the rules in the sphere of intellectual property is being one of the main indicators of evolution of society. The laws on copyright and related rights adopted within the period from 1992 to 2004 promoted the situation, in which the works of science, literature and art as well as the objects of related rights had become profitable objects of civil turnover. In the meantime the legislation of Russia had defined the balance between authors' rights and interests of society, in particular - in the area of education, scientific researches and access to information.

The applicable legislation of the Russian Federation narrowly regulates legal relations in the sphere of copyright when publishing articles in scientific journals. By virtue of article 2 of the Law of the Russian Federation of July 9, 1993 No. 5351-1 "About copyright and related rights" (as revised by the Federal laws of July 19, 1995 No. 110-Ф3 and of July 20, 2004 No. 72-Ф3) the legislation of the Russian Federation on copyright and related rights is based on the Constitution of the Russian Federation and consists of Civil Code of the Russian Federation, mentioned Law, the Law of the Russian Federation of September 23, 1992 No. 3523-1 "About legal protection of programs for electronic computers and databases" and federal laws.

At the present time the Russian Federation is being the party of the following international agreements regulating authorial legal relationships:

The Convention setting up World Intellectual Property Organization (Stockholm, July 14, 1967, amended of October 2, 1979; came into effect for the USSR on April 26, 1970);

Bernese Convention on protection of literature and artistic works (Berne, September 9, 1886, came into effect for the Russian Federation on March 13, 1995);

Universal Copyright Convention (Geneva, September 6, 1952, revised in Paris on July 1971, came into effect for the USSR on May 27, 1973);

International Convention on protection of rights of artists, manufacturers of phonograms and broadcast organizations (Rome, October 26, 1961, came into effect for the Russian Federation on May 26, 2003);

Convention on protection of interests of manufacturers of phonograms against illegal reproduction of their phonograms (Geneva, October 29, 1971, came into effect for the Russian Federation on March 13, 1995).

According to the article 1255 "About copyright" of Civil Code of the Russian Federation the intellectual rights for works of science, literature and art are being copyright. The following rights belong to an author: exclusive right for work, right of authorship, right of author for name, right of integrity of work, right of promulgation of work. In the cases provided by Civil Code of the Russian Federation an author of work together with the rights specified in clause 2 of article 1255 also possesses other rights, including the right of remuneration (royalty) for work for hire, right of withdrawal, resale royalty right, right for access to works of visual art (as revised by Federal Law of 03.12.2014 No. 35-Ф3).

The author of works of science, literature or art, in accordance with article 1257 of Civil Code of the Russian Federation, is the citizen, who had created it in the process of creative work. The person denoted as the author in original or copy of work or in other way in accordance with clause 1 of article 1300 of Civil Code of the Russian Federation is to be considered as its author, unless otherwise is proven (as revised by Federal Law of 03.12.2014 No. 35-Ф3).

The citizens created works in the process of mutual creative work are considered as co-authors regardless of whether such a work is being integral or consists of parts, each of which has independent significance (article 1258 of Civil Code of the Russian Federation).

The objects of copyright (article 1259 of Civil Code of the Russian Federation) are works of science, literature and art regardless of their merits, purpose and the way of their expression.

For emerging, realization and protection of copyright there is no need in registration of work or compliance with some other formalities.

The publisher of encyclopedias, encyclopedic dictionaries, periodical and continuing collections of scientific works, newspapers, journals and other periodicals possesses the right of use of such editions. Publisher has the right to denote its name or demand for its denotation when one uses its edition in this or that way. Authors or other owners of exclusive rights for works being part of such editions reserve these rights regardless of right of publisher 
or other persons for use of such editions as a whole, except for the cases when these exclusive rights were delivered to publisher or other persons or passed to publisher or other persons due to other reasons specified by law (article 1260 of Civil Code of the Russian Federation).

Without author's consent it is not allowed to introduce changes to his work, reduce it, supplement, illumine, add preface, epilogue, comments or any other explanations (right of integrity of work) (article 1266 of Civil Code of the Russian Federation).

An author possesses the right of promulgation of his work that means that he has the right to perform action or yield consent on performance of action, which for the first time makes the work accessible for general public by means of its publication, public demonstration, public performance, over-the-air or cable transmission or in any other way. The publication is to be considered as an utterance of copies of work presented by its copy in any material form, in quantity enough for satisfaction of reasonable needs of public on the assumption of the character of the work. The author passed his work for use by other person under contract is to be considered as agreed for promulgation of the work.

Agreement on the alienation of the exclusive right for work (article 1285 of Civil Code of the Russian Federation) is not subject to state registration, since for emerging, performance and protection of copyright there is no need in its registration or compliance with any other formalities (articles 1232 and 1259 of Civil Code of the Russian Federation). In accordance with agreement on the alienation of the exclusive right for work author or other copyright holder passes or is obliged to pass his exclusive right for work to buyer of such right. Under the license contract one party-the author or other copyright holder (licensor) - presents or is obliged to present to another party (licensee) the right of use of the work under conditions set by the contract (article 1286 of Civil Code of the Russian Federation). The license contract for granting right of use of work is not subject to state registration, since for emerging, performance and protection of copyrights there is no need in its registration or compliance with any other formalities. The license contract is made in written form. The contract for granting right of use of work in periodical print publication can be made in oral form.

The responsibility for infringement of exclusive right for work (as revised by Federal law of 03.12.2014 No. 35-Ф3). In the cases of infringement of exclusive right for work author or other copyright holder along with use of other applicable safety methods and responsibility measures set by Civil Code of the Russian Federation (articles 1250, 1252 and 1253) has the right in accordance with clause 3 of article 1252 of Civil Code of the Russian Federation to demand from violator payment of an indemnity (instead of compensation for losses) in an amount from ten thousand roubles to five million roubles that is determined at the discretion of court on the assumption of the nature of violation; or at double rate of cost of pirated copies of work; or at double rate of cost of right of work's use determined on the assumption of the cost, which under comparable circumstances is often collected for legitimate use of work in the way that was used by violator (article 1301 of Civil Code of the Russian Federation).

\subsection{General Description of Research}

The applied sociological research was conducted among scientific journals issued in Saint Petersburg. The main method of research was the method of expert survey. The experts were head editors and responsible persons of scientific journals. The survey was carried out with help of method of semi-structured interviews. The secondary method of research was the method of analysis of documents, in the capacity of which the information about journals set up on their web-sites and published in every issue of journal was taken. The survey was carried out in spring 2014.

In St. Petersburg about 650 scientific journals dedicated to different branches of knowledge is issued. The participators of survey were 46 journals representing the following fields of science: physics (4 journals), chemistry (3 journals), biology ( 3 journals), geography ( 2 journals), geology ( 2 journals), medicine (4 journals), mathematics (3 journals), programming ( 2 journals), economy (4 journals), sociology (3 journals), jurisprudence ( 3 journals), politology ( 2 journals), philosophy ( 2 journals), history ( 2 journals), engineering sciences (4 journals) and also the multidisciplinary journal making a specialty out of publication of scientific articles on related branches of knowledge (1 journal). The search for journals was held by means of "e-library" (Scientific electronic library) performing the computation of scientific citing index that means all the journals participated in survey are in the database of electronic library. The journals denoted together are not in the scientometrical databases of Scopus and Web of Science.

The journals participated in survey were classified not only on the basis of specificity of the branch of knowledge, in the framework of which they make speciality, but also on the basis of characteristics of initiating body. In this respect we have pointed out three groups of journals. The first group includes journals issued by higher education institutes (universities) that finance the issue of these journals (21 journals). The second group 
is presented with journals, the founders of which are organizations of different profiles that do not hold educational activity (for example, the journals issued under the aegis of Integration Committee of member states of EurAsEC, Secretariat of CIS Interparliamentary Assembly, Shipbuilders Association of Saint Petersburg and the Leningrad region, etc.). These organizations finance issue of the present journals ( 9 journals). The third group covers the journals issued by scientific centers and communities, which under their own steam look for the sources of financing for issue of journal (16 journals). According to the results of research the journals of these groups differ with realization of various copyright configurations in respect of publishing authors as well as with various strategies of behaviour when organizing the publication procedure.

\subsection{Publication of Scientific Articles and Copyright Agreement}

One of the important elements of realization of copyright is being copyright agreement, where there are rights of author and journal in respect of publishing article defined. The availability of the present agreement should guarantee the respect for rights of author and journal, including the enforcement of obligations in regard to counter-party in case of judicial proceedings. The conclusion of such agreement is being integral part of civilized practice for publication of scientific articles (Bliznets, 2014).

The research conducted by us shows that the standard for the practice for work with authors of scientific papers is the simplification of the procedure for conclusion of copyright agreement. The overwhelming majority of journals, regardless of the group they refer to, with some minor exceptions (only 3 of all the questioned journals make copyright agreements in written form on regular basis) doesn't conclude written agreements with authors (Tarando et al., 2014).

So, what advantages are taken by journals due to the absence of copyright agreement? Firstly, journals save expenses linked to the procedure for written conclusion of copyright agreements. It should be noted that they save not only material costs, but also the expenses of time. Practically all the questioned journals have mentioned this advantage.

Secondly, such an approach is being the guarantee for absence of judicial proceedings in case of non-compliance with the terms of the agreements. As we were explained in the office of one of juridical journals, if such copyright agreements concluded, the journal would be tired of judicial proceedings. Here we should say that judicial proceedings are being the matter of fear only for juridical journals, what is apparently related to the specificity of the sphere they deal with. The representatives of journals of other subject areas did not mentioned this moment.

Thirdly, journals have the opportunity for some maneuvers concerning authorial articles putting these or those article to different issues of journal. Thus, some journals practice issue of thematical numbers, where there are articles dedicated to some definite topic. And since such articles are delivered to journal separately, the staff of journal should at first accumulate them, what makes the dates of issue of such numbers (and correspondingly of articles that should make up such numbers) undefined. And since the dates of publication should be agreed in written agreement, its absence significantly facilitates the work of journals.

Fourthly, according to Russian legislation in the copyright agreement there should be author's royalty, its size and conditions for its payment agreed. And as it will be underlined further, Russian journals don't practice payment of royalty.

To make the copyright agreement in written form in Russian practice there should be exceptional conditions for publication of an article.

Firstly, among all the questioned journals only three technical journals pay royalty on the regular basis. These journals refer to the second group, i.e. they are sponsored by organizations, which do not hold educational activity (in our situation they are: Russian technical society of shipbuilders named after Krylov, A. N., the Shipbuilders' Association of Saint Petersburg and the Leningrad region, State Research Center of the Russian Federation JSC "Center of shipbuilding and shiprepairing technology"). As our research showed this is the exceptional condition for publication in Russian practice. The payment of royalty requires conclusion of copyright agreement and this is being usual practice for the present journals.

Secondly, the rest of journals after all from time to time and under exceptional circumstances can conclude copyright agreements in written form. The exceptions are made for foreign authors from Western Europe, USA and Canada. And here we talk not about initial publications of their articles, but about articles that had been earlier published in leading European or American journals and which are wished to be published in translate by Russian journals. It should be noted that such practice is typical for the group of journals working in the area of economy, sociology and politology. These journals are presented in the second group, as they are issued by 
non-governmental and political organizations (Sociological Society named after Kovalevsky M.M., Interparliamentary Assembly of EurAsEC and so on), and the journals issued by education institutions, as a rule, publish articles of workers of those very organizations. What is for the journals issued by different research centers and communities, they, as a rule, are presented with journals with small audience of readers, which are not able to pay remuneration to foreign author of article and the journal initially published the given article.

In case of publication of translated article there is written agreement concluded, where rights and liabilities of author, the journal initially published the article and the journal publishing its translated variant prescribed. As far as the reprinting of article moves Russian journal to the field of international practice for realization of copyright, it should conform to the rules and standards requiring obligatory conclusion of copyright agreement (Nikitina, 2014). We should also say that questioned journals mentioned the loyalty of western journals in respect of Russian journals wishing to reprint their articles in Russian. As a rule, western journals permit such reprinting at quite low price. In particular cases they even refuse royalty. Such policy of western scientific community in respect of Russian journals allows making full-featured scientific dialogue between western and Russian science.

Thirdly, copyright agreements in written form are concluded also in the case when author should be paid for publications, but the money is contributed not by himself, but by legal body, the role of which is played by organization he works for. As a rule, such organization is presented with large Russian state university. In such a case the university needs official confirmation of the fact of publication to make the payment in official way as well. Respondent representatives of such journals mentioned that if the payment is made by author himself, copyright agreement is not concluded. Some representatives of journals say also that universities even conclude with journals agreements for paid publication of their employees' articles, in which they stipulate the necessity of conclusion of copyright agreement in written form in every specific case.

As research showed the staff of journals has only vague idea about copyright (except for juridical journals) - respondents had not only confused "copyright" and "copyright agreements" notions, but also had been poorly aware of what exact rights should be allocated between author and journal and, consequently, were perplexed with the necessity for concluding any copyright agreements. As far as Russian legislation permits conclusion of copyright agreements in oral form in respect to the publication of articles in periodicals, the representatives of journals having learned about it from interviewer mentioned that it was the way of concluding copyright agreements in their journals. This means that relationships between authors and journals at the level of everyday practice are regulated in general by the system of informal standards, for the staff of journals has just dim idea about formal standards.

\section{Results and Discussion}

\subsection{Allocation of Copyright at Publication of Scientific Articles}

As we have said above, the staff of journals has only vague idea about what exact rights should be allocated between author and journal when publishing articles. Nevertheless, some author's rights turned out to be known to responsible persons of journals and this allowed us to reproduce factual picture of its (copyright) allocation in denoted sphere.

The general characteristic of copyright allocation is presented with different notion about its configuration in different journals. The representatives of some journals at first spoke that all the copyright rights had passed to publishing house. However later in the process of interview it had emerged that authors publishing in these journals had reserved some rights, mainly of inalienable nature.

Thus, an author reserves such an inalienable right as the right for the name. An article is issued under the name of author and when one refers to it he must specify the name of its author. All the questioned journals mentioned they had not faced the situation when author used pseudonym. Some respondents also mentioned that if such a situation occurred, the article would not be accepted for publication, for not only journal, but also author bears responsibility for what there was published in the article, while pseudonym exonerate author from any responsibility. This situation showed that author together with the right for the name should also specify it, what means the journal has the right to demand for specifying author's actual name.

In addition to the right for the name authors publishing in Russian journals preserve the right of reproduction of article or its fragments in their other works. However, there are some limitations that occur in consequence of emerging of journal's rights for the same article. One of such limitation is the necessity of specifying the name of journal, year of its issue and its number as the place of initial publication. Also among the journals there is no shared vision on how an article should be altered to be considered as original work. Thus, workers of some 
journals consider that two thirds of article should be altered, as it was considered in the Soviet times. The representatives of other journals declared that if $30 \%$ of an article was altered, it can be considered as new original work and in such a case there is no need for specifying the name of the journal, in which the initial variant was published.

Russian legislation also stipulates such a right of author as the right for royalty (Volynkina, 2014; Zimin, 2014c). The overwhelming majority of journals participated in survey do not pay such a royalty to authors. However, the journals that pay royalty mention that it is being quite slight (3 technical journals).

At the same time the representatives of journals issued by leading educational organizations mentioned that although royalty is not paid directly, in some such organizations there is indirect procedure for paying royalty the workers of correspondent organization take additional payments to basic wage for the published article. This releases above-mentioned group of journals from keeping additional accounting. At the same time such additional payments are not of systematic character: they exist not in all such organizations and, besides, the leadership of the named organizations on one day can adopt the payments and on the other day can cancel them. However, despite all these maneuvers such conditions for publication-when author has a chance of getting royalty for his article - are being privileged for Russian practice and that is why such journals have queues of authors of correspondent organization, who, by the way, can publish their article in these journals just one time in several years.

What is for the second group of journals, including the journals, which are issued by organizations that do not hold educational activity, the royalty for authors is regularly paid only by three technical journals and the royalty, as the representatives of these journals mentioned, is being tokenistic. In the meantime, such payments are being the pride of the present journals, for they make exception of generally accepted Russian practice. This turns out to be possible, as issuing of the present journals is financed by large shipbuilding organizations possessing definite materiel resources.

Other journals of the second group pay no royalty at all and, moreover, some of them charge authors for publication.

The same situation pertains to the journals of the third group presented by journals issued by research centers and scientific communities. These journals are not supported by any large organizations and they look for the sources of financing for performing publishing activities by themselves. And the authors make the most available source for them. In the journals there are tariffs for publication - the authors, who have no academic degree, should pay less, while the authors with academic degree are charged for more.

At the same time in Russia there is number of journals being in the list of Supreme Attestation Commission of the Russian Federation (SAC RF). This commission centrally performs confirmation of academic ranks and academic degrees graduated in leading universities and scientific organizations (in the Russian Academy of Sciences). According to the requirements of SAC the degree-seeking student to be graduated with academic degree should publish definite number of articles in journals being in the above-mentioned list. At the same time in accordance with those very requirements of SAC the journals being in the list shall print the articles of postgraduate students (students seeking for the degree of candidate of science) at no cost. However, journals try to side-step this requirement, for it directly affects their material interests. In this context two general strategies of journals' behaviour were identified.

The first strategy implies creation of conditions for "voluntariness" of payment. A postgraduate student is warned that free of charge basis of publication means presence of many postgraduate students wishing to publish their articles and that is why the date, when his article will be published, is undetermined. In such a way, the postgraduate student, who in accordance with conditions for studying in postgraduate courses must defend a thesis in time (he/she has three years for writing and defense of a thesis, where the procedure of defense itself implies availability of definite and quite prolonged time lag for meeting all the formalities and requirements), has nothing to do, but to agree to pay for publication of his article.

Some journals developed other strategies of legal collection of payment from postgraduate students. They inform the students that when selecting articles for publication the preference is given to the authors, who had taken out a subscription for the journal. The subscription is taken out for rather long period. The articles of those, who had refused to subscript for the journal, are laid on the shelf for undetermined time. As a result authors have to take out and pay the subscription for the journal.

We should note that you will not find the information about paid conditions for publication on any web-site of Russian journals. The only information you can find on the sites is that "publication of articles of postgraduate 
students is performed for free". Such information can be found on the web-sites of the journals being in the list of SAC, since this condition is stipulated by SAC for the journals that want to remain in the above-mentioned list.

Except for royalty, authors also have such a property right as the right for author's copy. In this case the strategies are also different. The majority of journals issued by universities answered that authors are not given the author's copy, but sent electronic models of articles. This allows saving expenses of journal. The journals participated in two other groups present the author's copy to authors, and if an article was written by two authors, the number of author's copies for every article depends on the policy of every specific journal. Thus, the journals practicing the taking out of subscription as the payment for publication present additional copies of journal for additional payment. The journals, in which the payment for publication is performed on wording "for editorial and printing services", present additional copies for each of co-authors for free.

What is for publishing houses, they primarily reserve the right for editing the text of article and change its name. In addition, publishing houses reserve the number of property rights that cover the right for distribution of journal and related rights for getting income.

The special attention should be paid to such a right reserved by journal as the right for promulgation of article by means of its allocation in the Internet. As far as journals make no copyright agreements with authors, the present right is reserved by journal on default. Authors have to comply with the policy of journal in regard to the organization of its (journal's) Internet-version. Thus, all the journals of the second and the third groups (i.e. the journals issued by organizations that do not hold educational activities and the journals issued by scientific centers and communities) have electronic version located in the Internet on the web-site of journal. What is for the journals issued by educational institutions, the electronic version at the moment of survey was available in 15 journals, in three more journals it was under development, and the rest of journals of the present group (3 journals) had only printed variant. This situation reflects conservatism in issuing management of scientific journals that is being peculiar to state universities. The journals, the founders of which are presented with universities, are issued in general from the moment of foundation of this or that university that, as a rule, pertains to the Soviet times, and management of university considers the work on issue of journal is well-organized indeed. And since performance of affairs on modernization of work with authors and readers of such journals requires funds, these universities are not always ready to allocate them for the named purposes.

In the meantime, journals, as a rule, have electronic versions and practically all the questioned journals have these electronic versions in opened access (only 2 journals were practicing paid access to numbers). Policies of different journals differ only with the aspect of how soon access to the recent numbers of journals should be opened. The terms of granting open access to the recent numbers fluctuate depending on journal in the range from three month to one year. Journal publishes the recent list of content on its web-site (sometimes the list of content is added with abstract and keywords to the article) and definite time later opens access to all the articles published in the present number.

Such policy of Russian journals reflects position that has been saving since the Soviet times and that defines knowledge as public domain, when everyone who has correspondent wish should have opportunity of unobstructed access to the source of knowledge and, subsequently, of improvement of his educational level. However journals have another, more pragmatic motives.

Another important motive for organization of free access to the archive of numbers is that journals are afraid of losing their readership. The journals questioned by us are not very famous in the environment of readers. Free access to articles gives assurance that this or that article will be read indeed, if a reader came to web-site of a journal will take an interest in it. Besides, this increases the possibility of that the article from journal will be cited somewhere, what as the result will influence the meaning of journal's impact-factor. This motive plays decisive role in determination of such policy of journal.

It should be noted that journals practicing paid access to their numbers mentioned that income they take at such approach is quite low.

Thereby, number of Russian journals prefers to pass expenditures on issuing of journal not onto consumers of informational product, their readers, but onto the authors of articles in cases when journal's staff has to look for funds on its issuing by themselves. In such a situation it would be reasonably to develop programs for governmental support of such journals and provide grants for scientific funds that would promote issuing of these or those journals. 


\subsection{Violations on the Part of Authors}

What is for the violations on the part of authors, journals point out the following types of them.

Firstly, it is the problem of plagiary. Authors perform borrowings of alien text and do not specify the source of borrowing. Thus, not all the journals perform check of the sent articles for plagiary. Such check is not performed by journals issued by universities, although their representatives participated in the interview mentioned that such check should be held. However the rules for acceptance of articles in such journals are admitted by administration of university-founder and that is why implementation of such a standard requires bulky bureaucratic procedure that should specify not only the program, with help of which articles should be checked for plagiary, but also the results of such check that would be good for acceptance of an article.

Regarding other journals we can say that not all of them perform such check. Here we should note that we have not found dependence between performance by journal of check for plagiary in sent articles and relegating journal to the second or the third group. The main indicator that influences on presence or absence of such check is the amount of articles that is published in its every number and, subsequently, the volume of material that should be prepared for publication. If this volume is quite big, a journal has to rely on honesty of authors, whose honesty often depends on their current interest. That is why journals working within branches of knowledge pertaining to social science and where there is no check for plagiary mentioned that they have to take complaints of the authors, whose works were borrowed from the articles published in the present journals without any references. In such a case the journal has to publish apologies and black-list the guilty author.

Secondly, it is non-compliance with deadlines specified by journals for adaptation of articles after their recension. Journals plan the next numbers and what articles should be published in them. Correspondingly, authors are informed about specific terms related to the terms of issuing of the next number. Such a problem was mentioned by the journals issued by independent centers and communities. The matter is that these journals, as it was said above, charge authors for payment for publication and, subsequently, have material cause in the fastest issuing of the article.

Thirdly, it is the cases when authors publish the same article in different journals. This problem is faced by journals of social science, in particular, the sociological and economical ones. However, the journals mentioned they had not applied and were not going to apply any sanctions to authors, except for verbal reproaches.

Such violations become possible, for in the majority of cases journals do not conclude copyright agreements. The savings on expenditures for such conclusion lead to the situation when journals sustain losses due to the dishonesty of authors. In addition, there is the absence of common base of articles published in Russian language, with help of which journals would be able not only to monitor the authors' borrowings that have no references to the source, but also prevent cases of publication of the same article in different journals.

\section{Conclusions}

In such a way, despite the fact that legal grounds of civilized turnover and protection of objects of intellectual property in Russia are being statutory stipulated and the main legal principles for using results of intellectual activity corresponding to the experience of developed countries are specified, the everyday practice in this area demonstrates significant stagnation in implementation of standards set by the right. The research conducted by us showed that realization of copyright in the sphere of publication of scientific articles in Russian scientific journals is mainly regulated by the system of informal standards. Among these standards there are actual standards that were accepted in the Soviet times, when the term of intellectual property itself was excepted from legal framework. One of such inherited standards is the irrelevance of making written copyright agreement. It is of interest that such practice realized by the journals that were issued as early as in the Soviet time is adopted by the journals that were found after reforms. The fact that copyright agreements are not concluded in written form is considered as normal state of things in Russian journals. Thus, North D. studying the processes of change of social institutions in the course of history came to the conclusion about extremely unprofitable mechanisms of such change that complicate the implementation of effective innovations, if, of course, such implementation is not supported by serious political force (North, 1987). That is why, to our opinion, the government, being such serious political force, should make efforts linked to adaptation of matters of control for fulfillment of legal standards in this area. The conclusion of copyright agreements would promote both-preventing authors' violations in regard to the most important principles of work with journals and bringing violators to responsibility.

Another method of struggle with authors' violations should be creation of common base of Russian-language articles issued on the territory not only of Russia, but also of states of CIS - especially as the grounds for such 
base already exist and presented with Scientific electronic library that estimates Russian index of scientific citing. The articles should be included into it just after editing and acceptance for publication. The present base should give opportunities for quick check of articles sent to journals for plagiary and also for identifying factors for acceptance of this or that article for publication in other journals.

The significant support for Russian journals issued by research centers and communities that look for fund for issuing of journal by themselves can be presented with various governmental programs promoting the development of science in the part of specific assistance provided for these or those scientific journals. In addition, Russian scientific funds issuing grants for scientific researches can provide special grants for scientific journals that publish the results of these researches.

\section{Acknowledgements}

Authors of the paper thank Afanasieva Irina Germanovna studied at postgraduate course of sociology faculty of State University of Saint Petersburg in 2011-2014 for conducting interviews with all the representatives of journals participated in survey and interpretation of obtained records.

\section{References}

Aldoshin, S. M., \& Tsyganov, D. I. (2013). Protection of intellectual property of academic sector of science. Intellectual property right, 2, 17-24.

Arnesen, C. P. (2014). Protection of traditional cultural expressions: An EU perspective. Journal of Intellectual Property Law and Practice, 9(5), 389-396. http://dx.doi.org/10.1093/jiplp/jpu042

Bently, L., \& Sherman, B. (2001) Intellectual Property Law. Oxford: Oxford University Press.

Blanco, W. T. A., \& Jacob, R. (1986). Patents, trademarks, copyright and industrial designs. London: Sweet \& Maxwell.

Bliznets, I. (2014). Government regulation of intellectual property. The legal aspects and the necessity. Intellectual property, Copyright and related rights, 10, 4-11.

Burfitt, B., \& Heathcote, M. (2014). Valuing footsteps-Towards a valuation model of indigenous knowledge and culture expression for the sustainability of indigenous people's culture. Journal of Intellectual Property Law and Practice, 9(5), 383-388. http://dx.doi.org/10.1093/jiplp/jpu043

Carruthers, B. G., \& Ariovich, L. (2004). The Sociology of Property Rights. Annual Review of Sociology, August, 23-46. http://dx.doi.org/10.1146/annurev.soc.30.012703.110538

Dobryakova, N. I. (2012). Some matters of limitation of copyright in respect of scientific and educational works. Intellectual property right, 1, 4-8.

Geider, C., \& Izyumenko, E. (2014). Copyrights on the Human Rights' Trial: Redefining the Boundaries of Exclusivity Through Freedom of Expression. International Review of Intellectual Property \& Competition Law, 45(3), 316-342. http://dx.doi.org/10.1007/s40319-014-0181-3

Gervais, D. J. (2002). Feist Goes Global: A Comparative Analysis of The Notion of Originality in Copyright Law. The Journal of the Copyright Society of the USA, 49(4), 356-368.

Harding, I., \& Sweetland, E. (2012). Moral rights in the modern world: Is it time for a change [rho] Journal of Intellectual Property Law and Practice, 7(8), 565-572. http://dx.doi.org/10.1093/jiplp/jps077

Kazi, I. (2011). The Cost of IP protection: Making Europe More Competitive. European Intellectual Property Review, 33(3), 189-190.

Kozinski, A. (2013). I Licensed Nimmer. The Journal of the Copyright Society of the USA, 60(2), 135-144.

Kunstadt, R. M. (2014). IP jury trials-Trouble ahead [rho] Journal of Intellectual Property Law and Practice, 9(8), 639-643. http://dx.doi.org/10.1093/jiplp/jpu072

Lavik, E., \& van Gompel, S. (2013). On the Prospects of Raising the Originality Requirement in Copyright Law: Perspective from the Humanities. The Journal of the Copyright Society of the USA, 60(3), 201-210.

Linet, O. (2000). Acquisition and sale of copyright for works of literature. Moscow: Aspect-Press.

Liptsik, D. (2002). Copyright and related rights. Moscow: UNESCO.

Makhonina, L. (2014). Notion and features of results of intellectual activity. Intellectual property, Copyright and related rights, 7, 47-57.

Malyshev, V. A., \& Pruel, N. A. (2014, April). Institutional problems of Bolonsky process: Calls for social 
management (pp. 106-110). Paper presented at Sixth International scientific conference "Applied Sciences and technologies in the Unites States and Europe: Common challenges and scientific findings". New York: Cibunet Publishing.

Nikitina, A. (2014). Copyright agreement with the participation of foreign persons. Intellectual property, Copyright and related rights, 3, 30-39.

North, D. C. (1987). Institutions, transaction costs, and economic growth. Economic Inquiry, 25(3), 419-428. http://dx.doi.org/10.1111/j.1465-7295.1987.tb00750.x

Pallante, M. A. (2013). Saluting Nimmer on Copyright. The Journal of the Copyright Society of the USA, 60(2), 145-157.

Pila, J. (2010). Who Owns the Intellectual property Rights in Academic Work. European Intellectual Property Review, 32(12), 609-613.

Popova, A. (2014). The role and significance of the right for getting remuneration in the system of intellectual rights. Intellectual property, Copyright and related rights, 6, 26-35.

Puekert, A. (2011). Intellectual Property as an End in Itself [rho] European Intellectual Property Review, 33(2), 67-71.

Rahmatian, A. (2013). Originality in UK Copyright Law: The Old "Skill and Labor" Doctrine Under Pressure. International Review of Intellectual Property \& Competition Law, 44(1), 4-34. http://dx.doi.org/10.1007/s40319-012-0003-4

Ramalho, A. (2014). Conceptualizing the European Union's Competence in Copyright-What Can the EU do [rho] International Review of Intellectual Property \& Competition Law, 45(2), 178-200. http://dx.doi.org/10.1007/s40319-014-0161-7

Roland, N. (2014). Calculating damages in copyright infringement actions under Belgian Law. Journal of Intellectual Property Law and Practice, 9(4), 292-297. http://dx.doi.org/10.1093/jiplp/jpt251

Semiletov, S. I. (2000). Information as special non-material object of a right. The state and the right, 5, 67-74.

Skopintsev, I. V. (2008). Legal foundation for protection of objects of intellectual property. Moscow: MSUEE.

Sudarikov, S. A. (2009). Intellectual property right. Moscow: Prospect.

Swedberg, R. (2003). Principles of Economic Sociology. Princeton: Princeton University Press.

Tarando, E. E., Rubtsova, M. V., Nikiforova, O. A., \& Sinyutin, M. V. (2014, April). Realization of copyright in Russia from the point of applied sociological analysis: Problems and peculiarities (pp. 110-111). Paper presented at Sixth International scientific conference "Applied Sciences and technologies in the Unites States and Europe: common challenges and scientific findings". New York: Cibunet Publishing.

The Witterm Groupe. (2011). European Copyright Code. European Intellectual Property Review, 33(2), 76-82.

Volynkina, M. (2014). The intellectual property right in the light of recent changes: Fast facts. Intellectual property, Copyright and related rights, 8, 4-15.

Zenin, I. A. (2012a). Personal non-property intellectual rights of author. Intellectual property right, 6, 3-5.

Zenin, I. A. (2012b). Subjects and objects of intellectual copyright. Intellectual property right, 4, 4-9.

Zimin, V. A. (2014a). Objects of intellectual rights and their classification. Intellectual property. Copyright and related rights, 7, 4-13.

Zimin, V. A. (2014b). Correlation between "intellectual property" and "intellectual rights" concepts under legislation of the Russian Federation. Intellectual property right, 5, 19-23.

Zimin, V. A. (2014c). The system of intellectual rights: The problem definition. Intellectual property, Copyright and related rights, 4, 47-59.

\section{Copyrights}

Copyright for this article is retained by the author(s), with first publication rights granted to the journal. This is an open-access article distributed under the terms and conditions of the Creative Commons Attribution license (http://creativecommons.org/licenses/by/3.0/). 